\title{
An assessment on dispersion of carbon monoxide from a cement factory
}

\author{
Gholamreza Goudarzi ${ }^{1}$, Rajab Rashidi ${ }^{2}$, Fariba Keishams ${ }^{3}$, Mahsa Moradi ${ }^{4}$, Shahram Sadeghi ${ }^{5}$, Fereydoun \\ Masihpour ${ }^{6}$, Mojtaba Shegerd ${ }^{6}$, Ehsan Abouee Mehrizi ${ }^{7}$, Mohammad Veysi Shikhrobat $^{8}$, Yusef Omidi Khaniabadi ${ }^{49^{*}}$
}

${ }^{1}$ Associate Professor of Environmental Health, Air Pollution and Respiratory Diseases Research Center, Ahvaz Jundishapur University of Medical Sciences, Ahvaz, Iran

${ }^{2}$ Assistant Professor of Occupational Health, Department of Occupational Health, Nutrition Health Research Center, School of Health, Lorestan University of Medical Sciences, Khorramabad, Iran

${ }^{3} \mathrm{MSc}$ Student of Environmental Health, Department of Environmental Health, School of Health, Isfahan University of Medical Sciences, Isfahan, Iran

${ }^{4} \mathrm{MSc}$ of Environmental Health, Air Pollution and Respiratory Diseases Research Center, Ahvaz Jundishapur University of Medical Sciences, Ahvaz, Iran

${ }^{5} \mathrm{MSc}$ of Environmental Health, Environmental Health Research Center, Kurdistan University of Medical Sciences, Sanandaj, Iran ${ }^{6} \mathrm{BSc}$ of Occupational Health, Health Center of East, Ahvaz Jundishapur University of Medical Sciences, Ahvaz, Iran

${ }^{7} \mathrm{PhD}$ Student of Environmental Health, Department of Environmental Health Engineering, School of Public Health, North Khorasan University of Medical Sciences, Bojnurd, Iran

${ }^{8}$ BSc of Health Services Administration, Health Center of East, Ahvaz Jundishapur University of Medical Sciences, Ahvaz, Iran ${ }^{9} \mathrm{MSc}$ of Environmental Health, Health Care System of Karoon, Ahvaz Jundishapur University of Medical Sciences, Ahvaz, Iran

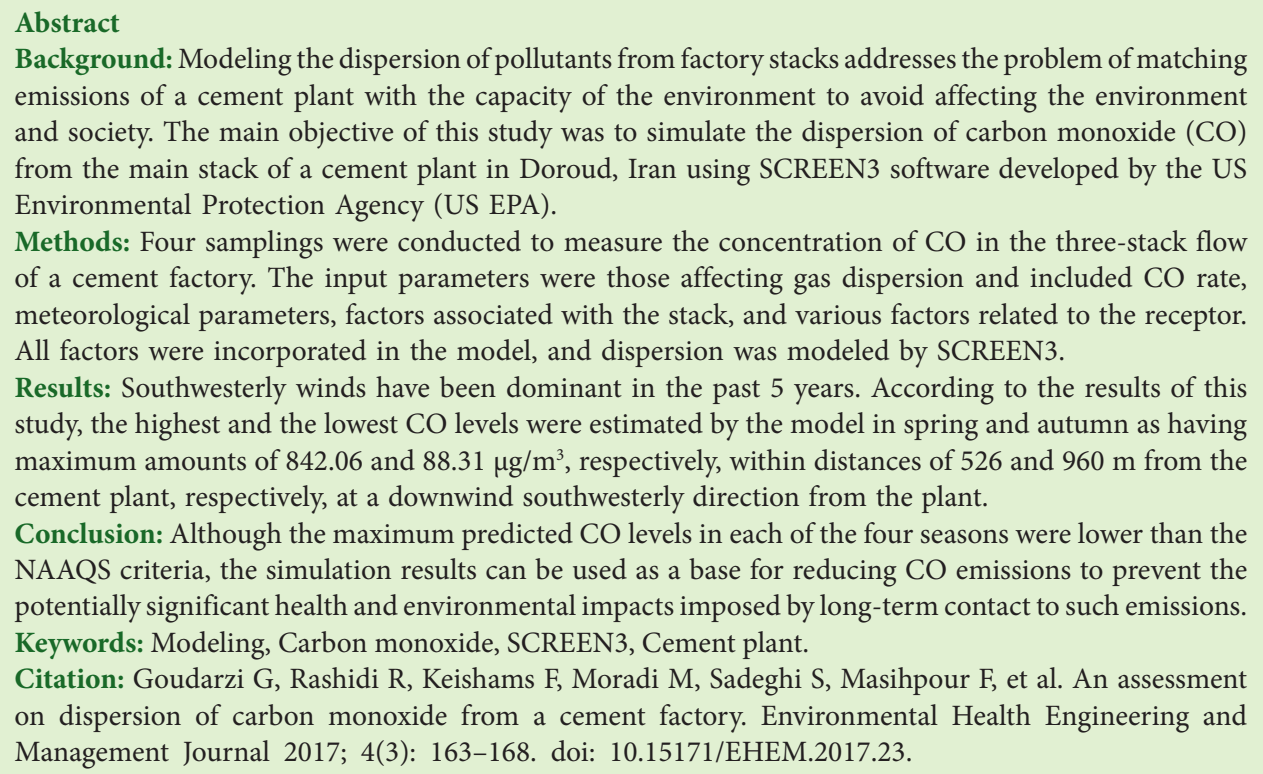
emissions of a cement plant with the capacity of the environment to avoid affecting the environment and society. The main objective of this study was to simulate the dispersion of carbon monoxide (CO) from the main stack of a cement plant in Doroud, Iran using SCREEN3 software developed by the US Environmental Protection Agency (US EPA).

Methods: Four samplings were conducted to measure the concentration of $\mathrm{CO}$ in the three-stack flow of a cement factory. The input parameters were those affecting gas dispersion and included $\mathrm{CO}$ rate, meteorological parameters, factors associated with the stack, and various factors related to the receptor. All factors were incorporated in the model, and dispersion was modeled by SCREEN3.

Results: Southwesterly winds have been dominant in the past 5 years. According to the results of this study, the highest and the lowest CO levels were estimated by the model in spring and autumn as having maximum amounts of 842.06 and $88.31 \mu \mathrm{g} / \mathrm{m}^{3}$, respectively, within distances of 526 and $960 \mathrm{~m}$ from the cement plant, respectively, at a downwind southwesterly direction from the plant.

Conclusion: Although the maximum predicted CO levels in each of the four seasons were lower than the NAAQS criteria, the simulation results can be used as a base for reducing $\mathrm{CO}$ emissions to prevent the potentially significant health and environmental impacts imposed by long-term contact to such emissions. Keywords: Modeling, Carbon monoxide, SCREEN3, Cement plant.

Citation: Goudarzi G, Rashidi R, Keishams F, Moradi M, Sadeghi S, Masihpour F, et al. An assessment on dispersion of carbon monoxide from a cement factory. Environmental Health Engineering and Management Journal 2017; 4(3): 163-168. doi: 10.15171/EHEM.2017.23.

Article History:

Received: 24 August 2016 Accepted: 24 April 2017 ePublished: 19 May 2017

\section{Introduction}

Air pollution attributable to the growth of industries is known as one of the environmental problems in the world, especially in Iran, a country that faces Middle Eastern Dust (MED) storms (1-5). Development in urban areas, increasing consumption of energy, and population growth are some of the most important factors that threaten health and environment (6-10). Combined cycle processes are the major sources of air pollutants in terms of quality and quantity of fuel combustion (11). When the fuels are burned, they emit toxins and global warming emissions, the most important of which are oxides of monoxide, oxides of sulfur, and dioxide, that are being discharged into the atmosphere (12-18).

The city of Doroud in Loresan province of western Iran is enclosed on three sides by the Zagros Mountains. Air 
pollutants, especially those from the Doroud Cement Plant and other industries associated with ruck extraction activities, have affected this city. The Doroud Cement Plant is located near the city center. Carbon monoxide (CO) emissions from the defective combustion of fuelburning process of this plant have caused inhabitants of the city to encounter large amounts of CO. The kiln fuel of this factory is natural gas through the first six months of the year; during autumn and winter, mazut is used.

Global concerns about CO emissions prompted the US Environmental Protection Agency (EPA) to establish primary and secondary standards for the concentration of $\mathrm{CO}$ in the air.

To diminish these concerns, it is important to identify how an air pollutant is dispersed in the troposphere $(13,19,20)$. Various parameters affect gas dispersion, including wind speed and direction, ground conditions, and atmospheric stability (19,21-23). Software tools based on Gaussian distribution are commonly used to estimate the concentrations of various pollutants (24). The application of atmospheric models provides information useful to atmospheric pollution control programs. The Gaussian model combines source linked factors and meteorological parameters from a source to assess a pollutant concentration. The model assumes that the pollutant does not undergo any chemical reaction and is not eliminated through other processes such as dry or wet deposition.

The basic equation for determining ground level concentrations using the Gaussian model (25) is presented in Eq. (1) and (2).

$$
\begin{aligned}
& \mathrm{X}=\frac{\mathrm{Q}}{2 \pi \mathrm{u}_{\mathrm{S}} \delta_{\mathrm{y}} \delta_{\mathrm{z}}}\left\{\exp \left[-0.5\left(\frac{\mathrm{z}_{\mathrm{r}}-\mathrm{h}_{\mathrm{e}}}{\delta_{\mathrm{z}}^{2}}\right)^{2}\right]+\exp \left[-0.5\left(\frac{\mathrm{z}_{\mathrm{r}}+\mathrm{h}_{\mathrm{e}}}{\delta_{\mathrm{z}}^{2}}\right)^{2}\right]+\mathrm{A}\right\} \\
& A=\sum_{N=1}^{K}\left[\exp \left(\frac{-0.5\left(z_{r}-h_{e}-2 \mathrm{Nz}_{\mathrm{i}}\right)}{\delta_{\mathrm{z}}}\right)^{2}+\exp \left(\frac{-0.5\left(\mathrm{z}_{\mathrm{r}}+\mathrm{h}_{\mathrm{e}}-2 \mathrm{Nz}_{\mathrm{i}}\right)}{\delta_{\mathrm{z}}}\right)^{2}\right. \\
& +\exp \left(\frac{-0.5\left(\mathrm{z}_{\mathrm{r}}-\mathrm{h}_{\mathrm{e}}+2 \mathrm{Nz}_{\mathrm{i}}\right)}{\delta_{\mathrm{z}}}\right)^{2} \\
& \left.+\exp \left(\frac{-0.5\left(\mathrm{z}_{\mathrm{r}}+\mathrm{h}_{\mathrm{e}}+2 \mathrm{Nz}_{\mathrm{i}}\right)}{\delta_{\mathrm{z}}}\right)^{2}\right]
\end{aligned}
$$

where $X$ is downwind concentration $\left(\mu \mathrm{g} / \mathrm{m}^{3}\right), \mathrm{Q}$ is emission rate $(\mathrm{g} / \mathrm{s}), \mathrm{u}_{\mathrm{s}}$ is wind speed at stack height $(\mathrm{m} / \mathrm{s}), \delta_{\mathrm{y}}$ and $\delta_{\mathrm{z}}$ are standard deviations of lateral and vertical dispersion $(\mathrm{m})$, respectively, $\mathrm{z}_{\mathrm{r}}$ and $\mathrm{z}_{\mathrm{i}}$ are the receptors height above ground level and mixing high $(\mathrm{m})$, respectively, and $\mathrm{h}_{\mathrm{e}}$ is central plume height (m).

The main objective of this study was to model CO emissions from the main stack of Doroud Cement Plant using SCREEN3 software.

\section{Methods}

\section{Study area}

Doroud Cement Plant $\left(33^{\circ} 29^{\prime} \mathrm{MN}, 49^{\circ} 4^{\prime} \mathrm{ME}\right)$ is one of the productive industries in the city of Doroud, Lorestan province, located in southwestern Iran (Figure 1). This factory started up in 1959 with a manufacturing capacity of 300 tons per day. Doroud Cement Plant is located in the vicinity of residential areas (26). Several atmospheric contaminants (such as CO) emitted from this factory can be harmful to the health of people living downwind of the cement factory.

\section{Measurement}

Conducted in 2014, this study performed sampling in four periods (May, August, November, and February) to measure the amount of $\mathrm{CO}$ emitted from the flow of three stacks. The CO samples were taken from the gas flow based on ASTMD5522-EPACTM-030 standard using Testo (XL350), which is a portable emissions analyzer designed for short-term industrial stack gas monitoring. This analyzer was calibrated by Behrooz measurement tools. It has an internal calibration with measurement accuracy of $\pm 2 \mathrm{mg}$ and response time of about one minute. To assess CO dispersion, the SCREEN3 model was used. Table 1 shows the results of measured data and $\mathrm{CO}$ concentrations.

\section{SCREEN3}

SCREEN3 (Likes Environmental Software, Waterloo, Ontario, Canada), developed by the US EPA, is software that predicts pollutant concentrations away from the source. In this study, SCREEN3 was used to simulate CO dispersion from the stack of a cement plant. This EPAapproved air dispersion model is a screening version of the Industrial Source Complex Dispersion Models (ISC3) and is used to analyze single-source release scenarios over simple or complex terrain. To estimate concentration, SCREEN3 incorporates different factors related to the source of the emission and meteorological parameters based on the Gaussian model $(15,27)$. SCREEN3 can be used for dispersion modeling at distances less than $100 \mathrm{~km}$ from the source (28). The data required to run the software includes source type, emission rate $(\mathrm{g} / \mathrm{s})$, source stack height $(\mathrm{m})$, stack inner diameter $(\mathrm{m})$, stack exit velocity $(\mathrm{m} / \mathrm{s})$, temperature of exit gas $\left({ }^{\circ} \mathrm{K}\right)$, air temperature $\left({ }^{\circ} \mathrm{K}\right)$, height of receptor from ground level $(\mathrm{m})$, wind direction, and urban or rural option. CO samples obtained from three stacks of the cement plant, including Electro filters 1 and 2 and Kiln (unit 3), and their averages were applied for the explication of the model during four seasons. Table

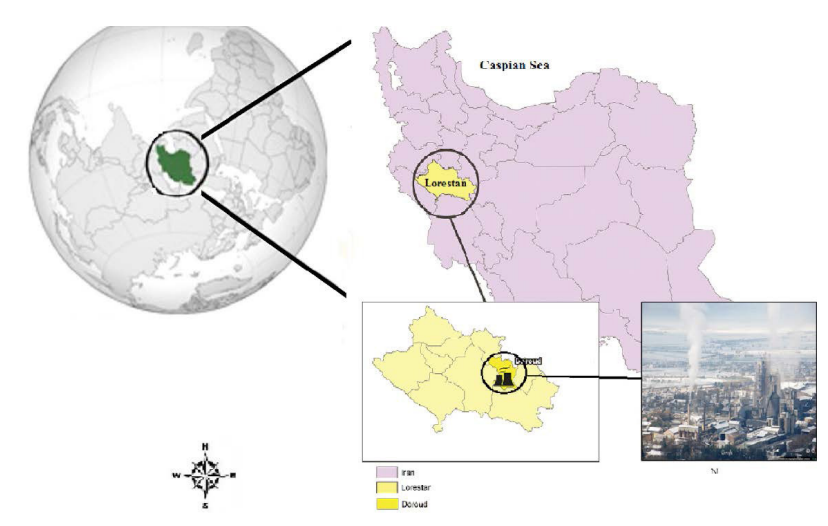

Figure 1. Doroud Cement Plant, the study area. 
Table 1. Data related to the cement factory stacks

\begin{tabular}{|c|c|c|c|c|}
\hline \multicolumn{2}{|c|}{ Number of stack } & \multirow{2}{*}{$\frac{\text { Unit } 1}{97.2}$} & \multirow{2}{*}{$\frac{\text { Unit } 2}{144.4}$} & \multirow{2}{*}{$\begin{array}{l}\text { Unit } 3 \\
222.2\end{array}$} \\
\hline $\mathrm{Q}\left(\mathrm{m}^{3} / \mathrm{s}\right)$ & & & & \\
\hline \multirow{3}{*}{ Spring } & Velocity of gas $(\mathrm{m} / \mathrm{s})$ & $7.8 \pm 1.3$ & $10.9 \pm 2$ & $12.7 \pm 1.6$ \\
\hline & Temperature of gas $\left({ }^{\circ} \mathrm{C}\right)$ & $160.22 \pm 22$ & $112 \pm 25$ & $71 \pm 12$ \\
\hline & $\mathrm{CO}$ (PPM) & $271 \pm 13.2$ & $252 \pm 12.08$ & $2378 \pm 76$ \\
\hline \multirow{3}{*}{ Summer } & Velocity of gas (m/s) & $182 \pm 8$ & $18.8 \pm 3.6$ & $11.6 \pm 0.5$ \\
\hline & Temperature of gas $\left({ }^{\circ} \mathrm{C}\right)$ & $33.22 \pm 5.4$ & $135 \pm 3.5$ & $80.3 \pm 9$ \\
\hline & CO (PPM) & $58 \pm 5.3$ & $220 \pm 7$ & $260 \pm 36$ \\
\hline \multirow{3}{*}{ Autumn } & Velocity of gas (m/s) & $176 \pm 13$ & $14.6 \pm 6.7$ & $14.6 \pm 6.7$ \\
\hline & Temperature of gas $\left({ }^{\circ} \mathrm{C}\right)$ & $36.1 \pm 2.1$ & $142 \pm 10$ & $142 \pm 10$ \\
\hline & $\mathrm{CO}$ (PPM) & $85 \pm 12$ & $141 \pm 16.9$ & $221 \pm 25.8$ \\
\hline \multirow{3}{*}{ Winter } & Velocity of gas (m/s) & $8.5 \pm 0.6$ & $14.8(2.6)$ & $9.1 \pm 5$ \\
\hline & Temperature of gas $\left({ }^{\circ} \mathrm{C}\right)$ & $166 \pm 26$ & $134 \pm 11$ & $89 \pm 4.9$ \\
\hline & CO (PPM) & $719 \pm 26.9$ & $426 \pm 16.9$ & $630 \pm 53.04$ \\
\hline
\end{tabular}

2 illustrates the physical factors related to units 1,2 , and 3 of the cement factory.

\section{Meteorological data}

The meteorological data required for this modeling effort was obtained from surface weather observatory stations located near the cement factory. Surface wind speeds and wind directions at $10 \mathrm{~m}$ above ground level were used in the meteorological analysis to evaluate the environmental impact (HIA) of CO emissions. The 5-year results of wind speeds and direction were obtained from the meteorological stations and then used to draw the wind rose plot using WRPLOT View software. For short time periods, a constant representative atmospheric stability was assumed.

Results

Figure 2 shows a five-year wind rose plot of wind speeds and directions based on the data recorded daily by the meteorological station in Doroud. Southwesterly winds dominated during these 5 years. The maximum percentage of time that wind blew from the dominant direction was $40 \%$.

The percentage of calm winds was zero. Wind speed ranged 17-21 knots per second.

The plots of different concentrations of CO predicted by the SCREEN3 at $\mathrm{X}$ downwind direction are illustrated in Figures 3 to 6 . As can be seen in these figures, the maximum predicted concentrations of $\mathrm{CO}$ in the warm seasons of spring and summer were 842.06 and $119.19 \mu \mathrm{g} /$ $\mathrm{m}^{3}$, respectively. Figures 4 and 5 also show the plots of CO

Table 2. Physical factors related to cement factory stacks

\begin{tabular}{lccc}
\hline Parameters associated with stack & Unit 1 & Unit 2 & Unit 3 \\
\hline Stack height $(\mathrm{m})$ & 54 & 70 & 90 \\
Stack diameter $(\mathrm{m})$ & 2.8 & 2.85 & 4 \\
\hline
\end{tabular}

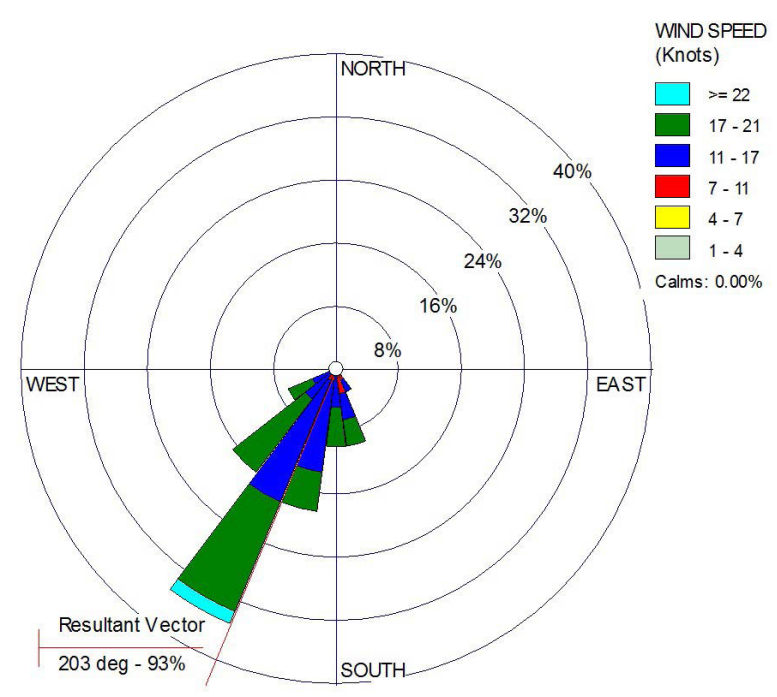

Figure 2. Five-year wind rose of wind speed and direction.

levels at different distances away from the plant during the autumn and winter seasons. As seen, the maximum estimated CO concentrations were 88.31 and $429.88 \mu \mathrm{g} /$ $\mathrm{m}^{3}$, respectively.

The figures also show that, for distances close to the source, the pollutant concentration was lower. At distances up to $526,584,960$, and $2647 \mathrm{~m}$ from the source, CO levels rapidly increased at ground level, and after drifting downward to a distance of $4000 \mathrm{~m}$, they were found to be $89.91,11.04,32.94$, and $425.52 \mu \mathrm{g} / \mathrm{m}^{3}$, respectively. Thus, the pollutants in the study area do not exceed the NAAQS standard. The worst atmospheric condition was noted in spring.

\section{Discussion}

In recent decades, air pollution has been considered a serious threat for the environment, the quality of human 


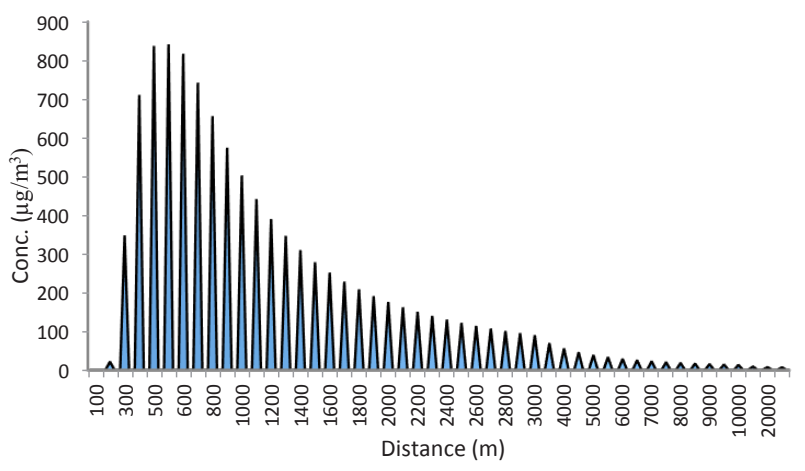

Figure 3. The concentration distribution of $\mathrm{CO}$ during spring.

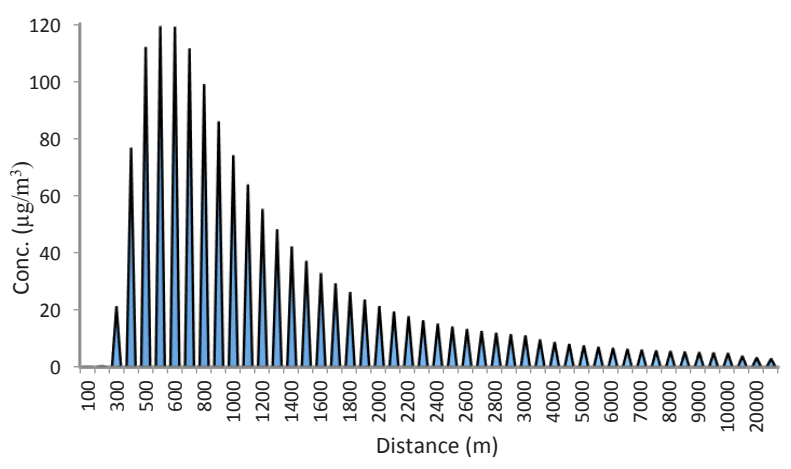

Figure 4. Concentration distribution of $\mathrm{CO}$ during summer.

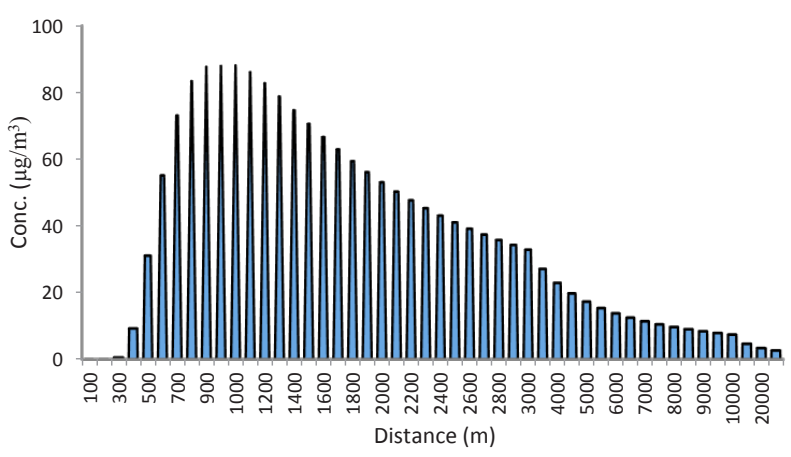

Figure 5. Concentration distribution of $\mathrm{CO}$ during autumn.

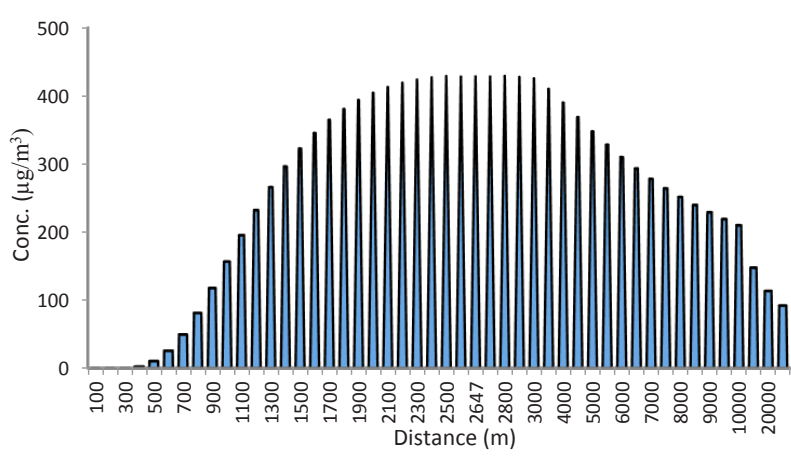

Figure 6. Concentration distribution of $\mathrm{CO}$ during winter. life, and human health around the world. The current study assessed the distribution of $\mathrm{CO}$ from the stacks of a cement plant in Doroud, Lorestan, Iran the SCREEN3 model. Southeasterly winds were dominant during this 5-year analysis of wind speeds and directions. Seangkiatiyuth et al showed that winds were below the instrument detection limit $6.9 \%, 17.7 \%$, and $47.8 \%$ of the one year (19). Abril et al reported stronger winds coming from a southerly direction, and these winds were more frequent than the others (29). These findings are consistent with the results of the current study. Maximum CO concentrations for the four seasons were estimated to be $842.06,119.19,88.31$, and $429.88 \mu \mathrm{g} / \mathrm{m}^{3}$ in spring, summer, autumn, and winter, respectively. The worst condition occurred in spring in an unstable condition in which the maximum concentration of pollutant measured near the cement plant was at a higher level than in the other seasons. Doroud is well known for the extraction and manufacture of rock materials as well as the existence of a large cement plant located in the vicinity of the city center which affects the quality of the air in nearby communities.

Major sources of $\mathrm{CO}$ that increase the risks from anthropogenic sources of air pollution are road traffic, defective combustion, and industrial processes. This can be seen in studies conducted in other industries with a wide range of basic conditions, such as population, climate, economic and social conditions, and pollutant concentrations. Few studies have investigated modeling CO exited from cement plant stacks. Sari et al showed the modeling of pollutants from the stacks of a palm oil mill using SCREEN3 software. The highest concentration of $\mathrm{CO}$ on the west and east was found to be $49.6 \mu \mathrm{g} / \mathrm{m}^{3}$ at an X downwind distance of $1403 \mathrm{~m}$ from the source (15). Maximum CO levels in spring, summer, autumn, and winter occurred within distances of 526, 584, 960, and $2647 \mathrm{~m}$ from the cement plant, respectively.

Abdulkareem et al illustrated that the simulated results are in good agreement with the dispersion pattern and that continuous gas flaring irrespective of the quantity will, in the long run, lead to changes in the quality of the physical atmosphere (30). Visscher showed that SCREEN3 is a good model for forecasting the distribution of air pollutants (31).

Abu-Allaban and Abu-Qudais predicted the concentration of CO gas emitted from a cement plant in Jordan using the AERMOD model. In their study, the maximum 1-hour predicted concentration of $\mathrm{CO}$ was estimated at 0.086 ppm at a distance of $2000 \mathrm{~m}$ from the source in a westeast direction (32); this is lower than the findings of the current study. Kahforoshan et al demonstrated that the maximum CO level in a stack in Nigeria was $14640 \mu \mathrm{g} / \mathrm{m}^{3}$ at a distance of $20 \mathrm{~m}$ from the stack at ground level (33). Maximum CO concentrations were lower than the US National Ambient Air Quality Standard (NAAQS) with an average value of $40000 \mu \mathrm{g} / \mathrm{m}^{3}$. This condition had no significant impact on the health of nearby communities settled in an $\mathrm{X}$ downwind from the south and east 


\section{direction.}

Otaru et al reported that, due to fugitive emissions from cement plants, a simulated distance of 7000 meter from the source is recommended for safe human settlement and activities (34). Schuhmacher et al indicated that exited pollutants from a cement plant stack are not considered causal predictors of mortality, but they increase by about $0.2 \%$ the risk of asthma visits (35).

Momeni et al modeled the spread of air pollution using SCREEN3 and meteorological information. Their measurements indicated that CO levels were lower than the standard (36), and this finding is consistent with the results of the present study.

\section{Conclusion}

The results of this study showed that the SCREEN3 software is one of the most effective models for estimating air pollutant distribution. The dominant direction of $\mathrm{CO}$ dispersion was from the southwest. The highest and lowest concentrations were predicted in spring and autumn, respectively. Maximum $\mathrm{CO}$ concentrations in different seasons were not higher than the NAAQS recommendations. Thus, it can be concluded that $\mathrm{CO}$ emissions from the cement plant have no impact on health in nearby communities. It is important to emphasize the fact that applying atmospheric dispersion models can be useful when they are applied together and with measured data in order to permit more robust and improved predictive atmospheric studies. In addition, to decrease emissions from fuel combustion, fuel type must be selected with attention to reducing $\mathrm{CO}$ concentrations. Although the maximum $\mathrm{CO}$ concentrations in four seasons predicted by SCREEN3 were lower than the NAAQS recommendations, the simulation results can be used as a base for reducing $\mathrm{CO}$ emission rates, because the long-term exposure to emissions of a cement plant imposes potentially significant health and environmental impacts.

\section{Authors' contributions}

Study concept, design, and critical revision of the manuscript for important intellectual content: G G, YOK, RR, MM, EAM; drafting of the manuscript and advisor YOK, GG, FK, MS, FM, SS, and performing experiments: MVS.

\section{Competing interests}

The authors declare that they have no competing interests.

\section{Ethical issues}

The authors certify that all data collected during the study is presented in this manuscript, and no data from the study has been or will be published separately.

\section{Acknowledgments}

The authors wish to thank the personnel of Doroud Cement Plant for their assistance in conducting this research (grant No. 1143).

\section{References}

1. Khaniabadi YO, Hopke PK, Goudarzi G, Daryanoosh SM, Jourvand $\mathrm{M}$, Basiri $\mathrm{H}$. Cardiopulmonary mortality and COPD attributed to ambient ozone. Environ Res 2017; 152: 336-41. doi: 10.1016/j.envres.2016.10.008.

2. Khaniabadi YO, Daryanoosh SM, Hopke PK, Ferrante M, De Marco A, Sicard P, et al. Acute myocardial infarction and COPD attributed to ambient $\mathrm{SO}_{2}$ in Iran. Environ Res 2017; 156: 683-687. doi: 10.1016/j.envres.2017.04.028.

3. Omidi Khaniabadi Y, Daryanoosh SM, Amrane A, Polosa R, Hopke PK, Goudarzi G, et al. Impact of Middle Eastern Dust storms on human health. Atmos Pollut Res 2017; 8(4): 606-13. doi: 10.1016/j.apr.2016.11.005.

4. Khaniabadi YO, Fanelli R, De Marco A, Daryanoosh SM, Kloog I, Hopke PK, et al. Hospital admissions in Iran for cardiovascular and respiratory diseases attributed to the Middle Eastern Dust storms. Environ Sci Pollut Res Int 2017; 24(20): 16860-8. doi: 10.1007/s11356-017-9298-5.

5. Goudarzi G, Daryanoosh SM, Godini H, Hopke PK, Sicard P, De Marco A, et al. Health risk assessment of exposure to the Middle-Eastern Dust storms in the Iranian megacity of Kermanshah. Public Health 2017; 148: 109-16. doi: 10.1016/j.puhe.2017.03.009.

6. Sepahvand A, Godini H, Omidi Y, Tarrahi MJ, Rashidi R, Basiri H. Investigation of fungal bioaerosols and particulate matter in the teaching-medical hospitals of Khorramabad City, Iran during 2015. Iran J Health Environ 2016; 9(1): 115-26. [In Persian].

7. Mohammadi MJ, Goudarzi G, Geravandi S, Yari AR, Ghalani B, Shirali S, et al. Dispersion modeling of nitrogen dioxide in ambient air of Ahvaz city. Health Scope 2016; 5(2): e32540. doi: 10.17795/jhealthscope-32540.7.

8. Nourmoradi H, Omidi Khaniabadi Y, Goudarzi G, Daryanoosh SM, Khoshgoftar M, Omidi F, et al. Air quality and health risks associated with exposure to particulate matter: a cross-sectional study in Khorramabad, Iran. Health Scope 2016; 5(1): e31766. doi: 10.17795/ jhealthscope-31766.

9. Daryanoosh SM, Goudarzi G, Khaniabadi YO, Armin H, Bassiri H, Khaniabadi FO. Effect of exposure to PM10 on cardiovascular diseases hospitalizations in Ahvaz, Khorramabad and Ilam, Iran during 2014. Iranian Journal of Health, Safety \& Environment 2016; 3(1): 428-33.

10. Dobaradaran S, Geravandi S, Goudarzi G, Idani E, Salmanzadeh S, Soltani F, et al. Determination of cardiovascular and respiratory diseases caused by PM10 exposure in Bushehr, 2013. J Mazandaran Univ Med Sci 2016; 26(139): 42-52. [In Persian].

11. Omidi Y, Goudarzi G, Heidari AM, Daryanoosh SM. Health impact assessment of short-term exposure to NO2 in Kermanshah, Iran using AirQ model. Environ Health Eng Manag J 2016; 3(2): 91-7.

12. Khaefi M, Geravandi S, Hassani G, Yari AR, Soltani F, Dobaradaran S, et al. Association of particulate matter impact on prevalence of chronic obstructive pulmonary disease in Ahvaz, southwest Iran during 2009-2013. Aerosol Air Qual Res 2017; 17(1): 230-7. doi: 10.4209/ aaqr.2015.11.0628.

13. Al Smadi M, Al-Zboon K, Shatnawi K. Assessment of air pollutants emissions from a cement plant: a case study in Jordan. Jordan of Civil Engineering 2009; 3(3): 265-82.

14. Zeleke Z, Moen B, Bratveit M. Cement dust exposure and acute lung function: a cross shift study. BMC Pulm Med 
2010; 10: 19. doi: 10.1186/1471-2466-10-19.

15. Sari N, Tarumum S, Saryono. Pollutant dispersion modelling (Dust, CO, NOx, and SOx) from palm oil mill stack. Indonesian Journal of Environmental Science and Technology 2014; 1(1): 28-34.

16. Neisi A, Goudarzi G, Babaei A, Vosoughi M, Hashemzadeh $\mathrm{H}$, Naimabadi A, et al. Study of heavy metal levels in indoor dust and their health risk assessment in children of Ahvaz city Iran. Toxin Rev 2016; 35(1-2): 16-23. doi: 10.1080/15569543.2016.1181656.

17. Yari AR, Goudarzi G, Geravandi S, Dobaradaran S, Yousefi F, Idani E, et al. Study of ground-level ozone and its health risk assessment in residents in Ahvaz City, Iran during 2013. Toxin Rev 2016; 35(3-4): 201-6. doi: 10.1080/15569543.2016.1225769.

18. Goudarzi G, Geravandi S, Mohammadi MJ, Salmanzadeh S, Vosoughi M, Sahebalzaman M. The relationship between air pollution exposure and chronic obstructive pulmonary disease in Ahvaz, Iran. Chronic Diseases Journal 2015; 3(1): 14-20.

19. Seangkiatiyuth K, Surapipith V, Tantrakarnapa K, Lothongkum AW. Application of the AERMOD modeling system for environmental impact assessment of $\mathrm{NO} 2$ emissions from a cement complex. J Environ Sci (China) 2011; 23(6): 931-40.

20. Guttikunda SK, Begum BA, Wadud Z. Particulate pollution from brick kiln clusters in the Greater Dhaka region, Bangladesh. Air Qual Atmos Health 2013; 6(2): 357-65. doi: 10.1007/s11869-012-0187-2.

21. Dimovska B, Šajn R, Stafilov T, Bačeva K, Tănăselia C. Determination of atmospheric pollution around the thermoelectric power plant using a moss biomonitoring. Air Qual Atmos Health 2014; 7(4): 541-57. doi: 10.1007/ s11869-014-0257-8.

22. Khaniabadi YO, Goudarzi G, Daryanoosh S, Borgini A, Tittarelli A, De Marco A. Exposure to PM10, NO2, and O3 and impacts on human health. Environ Sci Pollut Res Int 2017; 24(3): 2781-9. doi: 10.1007/s11356-016-8038-6.

23. Mohebbi A, Baroutian S. A Detailed Investigation of particulate dispersion from Kerman Cement Plant. Iranian Journal of Chemical Engineering 2006; 3(3): 65-74.

24. Hess GD. Simulation of Photochemical Smog in the Melbourne Air shed: worst case studies. Atmos Environ (1994) 1989; 23(3): 661-9. doi: 10.1016/00046981(89)90014-0.
25. Mohebbi A, Baroutian S. Numerical Modeling of Particulate Matter Dispersion from Kerman Cement Plant, Iran. Environ Monit Assess 2007; 130(1-3): 73-82.

26. Nourmoradi H, Khaniabadi YO, Goudarzi G, Jourvand M, Nikmehr K. Investigation on the dust dispersion (PM10 and PM2.5) by Doroud Cement Plant and study of its individual exposure rates. Journal of Ilam University of Medical Sciences 2016; 24 (1): 64-75. [In Persian].

27. Zhong S, Zhou L, Wang Z. Software for environmental impact assessment of air pollution dispersion based on ArcGIS. Procedia Environ Sci 2011; 10(Part C): 2792-7. doi: 10.1016/j.proenv.2011.09.433.

28. U.S. Environment Protection Agency. SCREEN3 Model User's Guide. USA: EPA; 1995.

29. Abril GA, Wannaz ED, Mateos AC, Pignata ML. Biomonitoring of airborne particulate matter emitted from a cement plant and comparison with dispersion modelling results. Atmos Environ. 2014; 82: 154-63.

30. Abdulkareem A, Odigure J, Abenege S. Predictive model for pollutant dispersion from gas flaring: a case study of oil producing area of Nigeria. Energy Sources, Part A 2009; 31(12): 1004-15. doi: 10.1080/15567030801909318.

31. Visscher AD. Air Dispersion Modeling: Foundations and Applications. Philadelphia: John Wiley \& Sons; 2013.

32. Abu-Allaban $M$, Abu-Qudais $H$. Impact assessment of ambient air quality by cement industry: a case study in Jordan. Aerosol Air Qual Res 2011; 11(7): 802-10. doi: 10.4209/aaqr.2011.07.0090

33. Kahforoshan D, Fatehifar E, Babalou AA, Ebrahimin AR, Elkamel A, Soltanmohammadzadeh JS. Modeling and evaluation of air pollution from a gaseous flare in an oil and gas processing area. WSEAS Conferences Santander; 2008 Sep 23-25; Santander, Cantabria; 2008.

34. Otaru AJ, Odigure JO, Okafor JO, Abdulkareem AS. Model prediction of particulate dispersion from a cement mill stack: case study of a cement plant in Nigeria. J Environ Sci Toxicol Food Technol 2013; 3(2): 97-110.

35. Schuhmacher M, Domingo JL, Garreta J. Pollutants emitted by a cement plant: health risks for the population living in the neighborhood. Environ Res 2004; 95(2): 198-206. doi: 10.1016/j.envres.2003.08.011.

36. Momeni S, Sekhavatjo M. Modeling of air pollution (case study: Lavan Island). 16th the National Conference on Environmental Health; 2013 Oct 1-3; Tabriz University of Medical Sciences, Tabriz; 2013. 